\title{
Entry Mode Selection, Location Choice and the Sequence of Internationalization: A Case Study on Ranbaxy Laboratories Ltd.
}

\author{
Md. Masrurul Mowla ${ }^{1}$, Nazamul Hoque ${ }^{1}$, Abdullahil Mamun ${ }^{1} \&$ Mohammad Rahim Uddin $^{1}$ \\ ${ }^{1}$ Department of Business Administration, Faculty of Business Studies, International Islamic University \\ Chittagong, Bangladesh \\ Correspondence: Abdullahil Mamun, Department of Business Administration, Faculty of Business Studies, \\ International Islamic University Chittagong, Bangladesh. Tel: 88-017-1213-8373. E-mail: \\ ahm_economics@yahoo.com
}

Received: December 15, 2013 Accepted: January 28, 2014 Online Published: February 26, 2014

doi:10.5539/ass.v10n6p145

URL: http://dx.doi.org/10.5539/ass.v10n6p145

\begin{abstract}
Due to increase of a good numbers of multinationals firms from emerging economies, researchers' attention have been paid toward understanding the internationalization sequence of these companies. For making the internationalization process successful, multinational enterprises (MNE) make some strategic decisions like entry modes selection, site selection very carefully and delicately. Since, pharmaceutical industry in India has been growing rapidly and achieved the recognition of the world as a high quality manufacturer at low cost, it is the interest of researchers to investigate how Indian emerging multinationals are taking decisions in case of entry mode selection and location choice. In this regard, Indian Multinational enterprise 'Ranbaxy Laboratories Limited' is an ideal case to study because it has developed its capabilities to compete against incumbent MNEs by using different motives, entry strategies and locations advantages. In this case study, relevant foreign direct investment (FDI) literature and other secondary sources have been used to analyze the strategies used in case of locations choice and entry modes selection for Ranbaxy's Outward Foreign Direct Investment (OFDI). It has been observed that in case of location choices and entry modes selection, decisions varied significantly for different regulated markets. Initially, Ranbaxy entered into Africa and Asian market and after gaining experiences and knowledge from there it moved to USA and Europe. The study reveals that Ranbaxy has chosen entry mode as 'acquisition' for USA and European market basically to overcome made-in-India image, credibility issues and quality concern. Furthermore, Ranbaxy offered their product and services more confidently as a guarantor of quality and safety standards due to acquisition strategy. Since, most of the European and North American markets were regulated and Ranbaxy entered these markets using unique entry modes. On the other hand, Asian and African markets were unregulated and entry modes were different from regulated markets. Ranbaxy entered first into the unregulated markets then moved to the regulated markets. For different segments Ranbaxy were driven by different motives. Thus, company developed experience and expertise from different markets. Apart from this, company found various types of capability handicaps in different markets and responded accordingly to overcome these handicaps. Consequently, these sequential developments have been transformed into ownership specific advantages for Ranbaxy's case. Considering extant strength and capabilities of Ranbaxy, market seeking motive could be the stimulating factor for Ranbaxy's next expansion for maintaining sustainable growth and position in the international market. European countries like Cyprus and Greece could be the location choice for next market expansion. In case of choosing European countries, Ranbaxy could minimize psychic distance, technological, economical, and institutional and location distance as it has strong local image in the European countries
\end{abstract}

Keywords: acquisition, join venture, FDI, regulated market, unregulated market

\section{Introduction}

Globalization and liberalization together have helped many developing countries to emerge from their regions and become part of the globalized world. Over the years, it has become increasingly evident that multinationals from emerging regions are changing the rules of the game by becoming dominant global players (Li, 2007; Nigam \& Su, 2010; Nigam \& Su, 2011). But, geographic country segmentation and selection decisions are the prime activities of firms entering into international market. From where to operate and in which portion 
operation takes place are the central points to for a firm while taking internationalization decisions (Yeoh, 2011). For these reasons, companies around the world have been making location decision as a strategy to reap benefits from different country specific resources (Krajewshi \& Ritzman, 2005). Indeed, a good geographic country selection is a must for ensuring efficiency with the help of centralization of various activities like manufacturing, service support, managing sales force and logistics. Apart from these some other issues like where, how and why are also vital questions for multinational enterprises in making strategic decision (MNE) regarding entry modes selection. Indian MNE 'Ranbaxy Laboratories Limited' is a perfect case to study the decision making process of emerging multinationals companies relating to entry mode selection and location choice. In addition, Ranbaxy's case study could help to find how emerging multinationals are developing capabilities to compete against incumbent MNEs by using different motives, entry strategies and locations advantages. It has been observed that the academics explained the internationalization process by using a stage model, which follows a step by step process where the firm starts from no international activity and goes on to engage in some international activity and then ends up owning subsidiaries abroad (Masum, 2012, p. 171). Such is the case of the Uppsala Model proposed in 1977 by Johanson and Vahlne. Right from the beginning this model has been criticized and after much criticism by scholars and other authors such as Andersen (1993), Johanson and Mattson (1988) introduced a new model known as 'The Network Approach', where they explained the importance of relationships with suppliers, customers and market that can stimulate or help a firm to go abroad.

Due to increase of a good numbers of multinationals from emerging economies, researchers attention have been paid for investigating the sequence of internationalization of these organizations (Nigam \& Su, 2011). Existing theories of FDI like 'OLI framework' and the 'Uppsala Stage Model' might be relevant in explaining Ranbaxy's case. Firstly, the eclectic paradigm (OLI) highlights that transaction cost and ownership advantage stimulate firms to the internationalization process (Dunning, 1988). Dunning (2000) states that asset seeking, market seeking and efficiency seeking motives are the main driving forces to the firm's internationalization. Secondly, the 'Uppsala Stage Model' that recognize the sequential progress of internationalization process, initially a firm starts via exporting then move to joint venture, contract manufacturing, production and so on (Johnson \& Vahlne, 1977).

In this case study, relevant FDI literature and other secondary sources have been used to analyze the strategies used in case of locations choice and selection of entry modes for Ranbaxy's Outward Foreign Direct Investment (OFDI). This article has been designed into four sections. A brief description of Ranbaxy and Indian pharmaceutical market has been placed in the first section. In the second section, the whole international market has been divided into six geographic regions: 'African and Asian market', 'Russian market', 'North American market', 'European market', New-Zealand, 'Latin America, Australia and South African market' and 'Japanese market', based on country specific homogeneous rules and regulations. Sequentially, a brief discussion on why and how Ranbaxy entered that market has been placed for every market segments. In the third section a justified future export marketing plan has been placed for the Ranbaxy's case. Finally a short theoretical analysis and an inference have been drawn with concluding remarks.

\subsection{Background of Indian Pharmaceutical Industry and Ranbaxy}

Pharmaceutical industry in India has been growing rapidly and gained global recognition as a high quality producer at low cost due to favorable policy support of Government of India (Athreye, Kale, \& Ramani, 2009). India has captured $8 \%$ market share in terms of volume and $22 \%$ in terms of value in the world market of generic drugs (Sampath, 2005, p. 15; Yeoh, 2011). Statistics signifies that India has 75 manufacturing units which are approved by the United States Food and Drug Administration (USFDA) and it is the largest number in the world other than United States (Chittor \& Ray, 2007). In fact, the comparative advantage of pharmaceuticals industry of India is the outcome of the flexible provision of Patent Act of 1970, which favorably impacted the Indian industry to create a niche for itself. Because, that flexibility enabled the Indian companies to imitate the patented products of the foreign companies, master the technique of reverse engineering and in most cases to come out with even better process technology for the same product (Chaudhury, 1997, 2004; Kumar, 2002).

Ranbaxy Laboratories Limited was established in 1961 and which is the largest pharmaceutical company in India generating $70 \%$ of total revenues from foreign markets (www.ranbaxy.com). Ranbaxy started as a local producer of Active Pharmaceutical Ingredients (API) and soon entered international markets searching market potentials. Ranbaxy first established a subsidiary in Nigeria through a joint venture in 1977 and moved to Malaysia in 1984 with the aim of expanding international presence (www.ranbaxy.com). The whole evolution of Ranbaxy has been shown in Table 4 end of the next section. 


\section{Ranbaxy's Internationalization and Market Expansion Globally}

\subsection{African and Asian Market}

Dixit and Yadav (2008) stated that first entry of Ranbaxy into African and Asian market was facilitated by harmonized regulatory measures between home and host countries. Market requirements in the host countries in Asia and Africa were similar to the local demand which is another reason to select these locations in the early age of international expansion. Market seeking motive was the main driving force of Ranbaxy to enter African and Asian markets. In these market Ranbaxy's entry strategy was joint venture. Two main reasons played an important role in choosing entry mode. First, due to long presence in the domestic market Ranbaxy developed expertise on low cost production capacity and used this ownership advantage in the host countries. Second, as a producer of API, joint venture in the generic production plants helped exporting pharmaceutical ingredients to those countries. Consequently Ranbaxy expanded the market share in Africa and Asia as well as increased volume of API exports from home country. Table 1 depicts era and entry strategies used Ranbaxy for African and Asian market.

Table 1. Era and entry strategies used for African and Asian market

\begin{tabular}{|c|c|c|c|}
\hline Name of the firm & Year of entry & Markets entered & Market entry strategy \\
\hline \multirow{4}{*}{ Laboratories } & 1977 & Nigeria & Joint Venture \\
\hline & 1983 & Malaysia & Joint Venture \\
\hline & 1987 & Thailand & Joint Venture \\
\hline & 1993 & China & Joint Venture \\
\hline
\end{tabular}

Source: Developed by the authors based on company website and annual reports

\subsection{Russian Market}

Ranbaxy entered the Russian market in 1993. Initially, bilateral agreement between home and host country governments helped Ranbaxy's internationalization efforts. Ranbaxy first entered the Russian market following exporting, because of barriers on currency exchange only product exchange was approved between countries. Since exchange of currency was strictly controlled by both governments, so other regulatory measures to trade were substantially flexible which favored Ranbaxy's market share expansion in Russia. Due to centrally planned economy essential commodities transaction and distribution process were fully controlled by central government. So, market entry and expansion were relative easy since Ranbaxy had to maintain lobby with the central government only.

\subsection{North American Market}

Entry requirements in the USA were stringent because of highly regulated nature of market which was difficult to comply and required long time for planning. In 1995, the US market was opened for generic pharmaceutical products, which was an ideal timing for Ranbaxy to enter. Because of import restrictions, brand image crises for being an emerging MNE, stringent standard issues and US government's investment seeking motive Ranbaxy used acquisition as entry strategy (See Table 4). The USA government enacted 'Waxman-Hatch act, in 1984 with a view to ensure enough supply of less costly generics drugs. Side by side, FDA was permitted to approve applications of generic versions brand name drugs without conducting costly and duplicative clinical trials (Dixit \& Yadav, 2008). This new regulations stimulated the Indian firms to exploit the benefits of imitative capabilities and learning to compete with formidable competitors. Ranbaxy acquired Ohm Laboratories in 1995 in order to ensure manufacturing support to exploit market opportunities.

\subsection{European Markets}

Ranbaxy's first entry in Europe was followed by owning a subsidiary company in the UK. To exploit the potentials EU market aside from image crisis Ranbaxy established production plant to be treated as local company in all EU member states. In 1994 Ranbaxy was enlisted on the Luxembourg stock exchange to accumulate financial support for its expansion in European market. Generic drug market in the European countries was more complex than US market because most of the countries in Europe had a policy of generic substitution and unique barriers to entry (Reiffen \& Ward, 2005; Yeoh, 2011). To face these challenges Ranbaxy focused first into generic products segment, establishing strong foothold moved to selective (prescription) products. Table 2depicts the European market entry sequences and strategies. 
Table 2. Era and entry strategies used for European market

\begin{tabular}{|c|c|c|c|}
\hline Name of the firm & Year of entry & Markets entered & Market entry strategy \\
\hline \multirow{6}{*}{$\begin{array}{l}\text { Ranbaxy } \\
\text { Limited }\end{array}$} & 1994 & UK & Wholly owned subsidiary \\
\hline & 1995 & Ireland & Acquisition \\
\hline & 2000 & Germany & Acquisition \\
\hline & 2003 & France & Acquisition \\
\hline & 2005 & Spain and Portugal & Acquisition \\
\hline & 2006 & Belgium and Romania & Acquisition \\
\hline
\end{tabular}

Source: Developed by the authors based on company website and annual reports

\subsection{Australia, New-Zealand, Latin America and South African Market}

'Latin America, South Africa, Australia, and New-Zealand market were clustered together because of their homogeneous regulatory requirements. These markets termed as semi-regulated market because the regulations of these markets were not as flexible as Asia and Africa, and not as astringent as EU and North America (Yeoh, 2011). Ranbaxy entered these markets through marketing subsidiary or acquisitions. For the generic market they had tough barriers to entry and were less competition. To overcome the high entry barriers acquisition was the right strategy entering in the generic market. Apart from this, to overcome the made-in-India, credibility and quality image acquisition was the right selection for these semi-regulated markets. However, their enhanced healthcare expenditure as well as growing infrastructure of healthcare, these markets offered high price margin compare to highly regulated markets (Dixit \& Yadav, 2008). Another motivation of the markets was their association in patent law and execution along with that of the developed countries (Chittoor \& Ray, 2007). Table 3 below shows some entry strategies of Ranbaxy to the above mentioned markets.

Table 3. Era and entry strategies for Australia, New-Zealand, South Africa and Latin American market

\begin{tabular}{llll}
\hline Name of the firm & Year of entry & Markets entered & Market entry strategy \\
\hline \multirow{2}{*}{ Ranbaxy Laboratories } & 2000 & Brazil & Marketing subsidiary \\
Limited & 2004 & Mexico & Wholly own subsidiary \\
& 2007 & South Africa & Acquisition \\
\hline
\end{tabular}

Source: Developed by the author based on company website and annual report

\subsection{Japanese Market}

Historically Japanese are highly conservative to foreign brands which motivated Ranbaxy to enter Japanese market by joint venture (See Table 4). Japan is the second largest market for pharmaceutical products in the world but generic products market is only 5 percent of the total demand for drugs (Dixit \& Yadav, 2008). Ranbaxy adopted a conservative strategy entitled 'wait-and-see, approach for the market of Japan that was seemed to be similar, short of transparency as well as influenced by the pharmaceutical companies of Japan. Considering the increasing number of aging population of the country and healthcare cost, Japanese government introduced a generic substitution law in 2006. By this law, generic products market was boosted up and medical institutions enabled dispensing generic drugs. Anticipating the new legislation, Ranbaxy increased its equity share from 10 percent to 50 percent with Nihon pharmaceuticals in 2005 (Yeoh, 2011).

Table 4. Ranbaxy's whole scenario of internationalization and other achievements

\begin{tabular}{lll}
\hline Year & Markets entered & Market entry strategies and other achievements \\
\hline 1961 & & Company established in India \\
& & Established API plant in India \\
1973 & & Ranbaxy goes public (IPO: India) \\
1977 & Nigeria & Joint venture (Manufacturing and Marketing) \\
1983 & Malaysia & Joint venture (Manufacturing and Marketing) \\
\hline
\end{tabular}




\begin{tabular}{|c|c|c|}
\hline Year & Markets entered & Market entry strategies and other achievements \\
\hline & & Dosage plant: India \\
\hline \multirow{2}{*}{1987} & \multirow{2}{*}{ Thailand } & Joint venture (Marketing) \\
\hline & & State of the art manufacturing plant in India \\
\hline \multirow{2}{*}{1992} & \multirow{2}{*}{ Hong Kong } & FDI \\
\hline & & Joint manufacturing agreement with Eli Lily \\
\hline \multirow{3}{*}{1993} & \multirow{3}{*}{$\begin{array}{l}\text { China } \\
\text { Canada }\end{array}$} & Joint venture (Manufacturing and Marketing) \\
\hline & & Wholly owned subsidiary \\
\hline & & A new research driven NCE and NDDS is launched \\
\hline \multirow{3}{*}{1994} & \multirow{3}{*}{$\begin{array}{l}\text { USA } \\
\text { England }\end{array}$} & Wholly owned subsidiary \\
\hline & & Wholly owned subsidiary \\
\hline & & Listing in Luxembourg stock exchange \\
\hline \multirow{3}{*}{1995} & \multirow{3}{*}{$\begin{array}{l}\text { USA } \\
\text { Ireland }\end{array}$} & Acquisition (Ohm laboratories) \\
\hline & & Manufacturing plant \\
\hline & & New FDA approved manufacturing plant \\
\hline \multirow{3}{*}{1998} & \multirow{3}{*}{$\begin{array}{l}\text { South Africa } \\
\text { USA }\end{array}$} & Wholly owned subsidiary \\
\hline & & Marketing own branded drugs \\
\hline & & Launches clinical trials on first in-house developed molecules \\
\hline \multirow{3}{*}{2000} & Germany & Acquisition (Basics) \\
\hline & Brazil & Majority owned equity \\
\hline & Vietnam & Manufacturing \\
\hline \multirow{2}{*}{2002} & USA & Acquisition (Signature pharmaceuticals) \\
\hline & Japan & Acquisition ( $10 \%$ stake) \\
\hline \multirow{2}{*}{2003} & \multirow{2}{*}{ France } & Acquisition (Aventis) \\
\hline & & Form alliance with GSK for drug development \\
\hline 2004 & Mexico & Wholly owned subsidiary \\
\hline 2005 & Spain & Acquisition (Efarmes S.A.) \\
\hline \multirow{4}{*}{2006} & USA & Acquisition (Sentek) \\
\hline & Belgium & Acquisition (Ethimed NV) \\
\hline & Italy & Acquisition (Allen SpA) \\
\hline & Romania & Acquisition (Terapia) \\
\hline 2007 & South Africa & Acquisition (Be-Taps) \\
\hline 2009 & & Ranbaxy launches First to File (FTF) product \\
\hline \multirow{2}{*}{2010} & & Enters its golden jubilee year \\
\hline & & It delivers quarterly sales over $\$ 500$ million for the first time. \\
\hline
\end{tabular}

Source: Developed by the authors based on company website, annual reports and literature

\section{Future Entry Plan of Ranbaxy}

Considering extant market regulatory conditions three categories of markets have been identified: unregulated, semi-regulated and regulated (Yeoh, 2011). These world market's regulatory conditions played an important role in firm's strategic decision making process. In the previous discussion of Ranbaxy's internationalization process, it has been observed that in case of location choices and entry modes selection, decisions varied significantly for different regulated markets (See Table 4). Most of the European and North American markets were regulated and Ranbaxy entered these markets using unique entry modes (See Table 5). On the other hand, Asian and African markets were unregulated and entry modes were different from regulated markets (See Table 4). Ranbaxy entered first into the unregulated markets then moved to the regulated markets. 
Table 5. Ranbaxy's acquisition history

\begin{tabular}{|c|c|c|c|}
\hline Acquired Company & Year & Country & Purpose \\
\hline Ohm laboratories & 1995 & USA & $\begin{array}{l}\text { Entered into the over the counter (OTC) market of US. } \\
\text { Advanced capabilities of manufacturing, infrastructure of } \\
\text { Marketing }\end{array}$ \\
\hline Basics GmBH & 2000 & Germany & Former generic business of Bayer \\
\hline \multirow{3}{*}{ RPG (Aventis) } & \multirow{3}{*}{2003} & \multirow{3}{*}{ France } & $\begin{array}{l}\text { Drive the position of Ranbaxy's to be the fifth biggest provider } \\
\text { of generics drugs in France }\end{array}$ \\
\hline & & & $\begin{array}{l}\text { Entered into key therapeutic market such as, anti-infective, } \\
\text { Cardiovascular, Gastrointestinal, Rheumatoid/Non-steroidal } \\
\text { anti-inflammatory drug, Neurology and Analgesics }\end{array}$ \\
\hline & & & $\begin{array}{l}\text { Aventis was also supported by a strong field force, business } \\
\text { development and regulatory team. }\end{array}$ \\
\hline Efarmes S.A. & 2005 & Spain & $\begin{array}{l}\text { Gained access to } 18 \text { products in the Cardiovascular system } \\
\text { (CVS), Central nervous system (CNS) and Pain management } \\
\text { system. }\end{array}$ \\
\hline Sentek & 2006 & USA & $\begin{array}{l}\text { Acquired patent, trademark and equipment used for the } \\
\text { self-administration of medicine. }\end{array}$ \\
\hline $\begin{array}{l}\text { Allen SpA, a division } \\
\text { of Glaxosmith Kline }\end{array}$ & 2006 & Italy & $\begin{array}{l}\text { Allen SpA's product portfolio complements Ranbaxy's own } \\
\text { pipeline of products for the Italian markets. }\end{array}$ \\
\hline Ethimed NV & 2006 & Belgium & $\begin{array}{l}10^{\text {th }} \text { biggest generic producing organization in Belgium. } \\
\text { Ethimed proposes Ranbaxy good networks of distribution and a } \\
\text { good foundation to run company's activities and operations in } \\
\text { the territories of Benelux. }\end{array}$ \\
\hline Terapia & 2006 & Romania & $\begin{array}{l}\text { Terapia is the biggest autonomous generic manufacturing } \\
\text { organization in Romania. The acquisition helped Ranbaxy to } \\
\text { enter into two production plants along with } 157 \text { drugs including } \\
\text { huge range of ailments relating to the central nervous system as } \\
\text { well as the heart. }\end{array}$ \\
\hline Be-Taps & 2007 & $\begin{array}{l}\text { South } \\
\text { Africa }\end{array}$ & $\begin{array}{l}5^{\text {th }} \text { biggest pharmaceutical company in producing penicillin } \\
\text { formulation. In the market of South Africa. }\end{array}$ \\
\hline
\end{tabular}

Source: Developed by the authors based on company website, annual reports and literature

Market seeking, resource seeking, efficiency seeking and strategic asset seeking (Dunning, 1993) motives were the main driving forces entering international market. For different segments Ranbaxy were driven by different motives. Thus, company developed experience and expertise from different markets. Apart from this, company found various types of capability handicaps in different markets and responded accordingly to overcome these handicaps (See Table 6 in summarized form, detailed in Appendix 1). Consequently, these sequential developments have been transformed into ownership specific advantages for Ranbaxy's case. These advantages in turn substantiate to establish a strong foothold in the European market.

Table 6. Marketwise capability lacking and responses to overcome

\begin{tabular}{|c|c|c|}
\hline Market & Capability lacking & Responses to Overcome \\
\hline Russia & Internationalizations exposure & $\begin{array}{l}\text { The supports of the firms relating to Environmental } \\
\text { issues in the bi-lateral form of agreement with the } \\
\text { government of Russian helped companies to } \\
\text { internationalize. }\end{array}$ \\
\hline $\begin{array}{l}\text { Africa and South } \\
\text { East Asia }\end{array}$ & WHO-cGMP plant & Firms upgraded/set up WHO-cGMP plant \\
\hline \multirow[b]{2}{*}{ Latin America } & Knowledge of internationalization & \multirow{2}{*}{$\begin{array}{l}\text { The freedom given to the employees of the firms } \\
\text { helped to learn the new skills by trial and error } \\
\text { method. Hired lawyers having international } \\
\text { exposure for setting up IP cell in the firm with the } \\
\text { employees having sufficient legal and practical }\end{array}$} \\
\hline & $\begin{array}{l}\text { Knowledge of Intellectual Property } \\
\text { Right (IPR) }\end{array}$ & \\
\hline
\end{tabular}




\begin{tabular}{|c|c|c|}
\hline Market & Capability lacking & Responses to Overcome \\
\hline & & knowledge. \\
\hline USA and Europe & $\begin{array}{l}\text { USFDA/IP knowledge/knowledge of } \\
\text { internationalization }\end{array}$ & $\begin{array}{l}\text { Upgraded plant to USFDA requirements/hired } \\
\text { international consultants. }\end{array}$ \\
\hline Japan & Non-availability of guidelines & Japanese government opened up the market \\
\hline
\end{tabular}

Source: Developed by the authors based on company website, annual reports and literature

Considering extant strength and capabilities of Ranbaxy, market seeking motive could be the stimulating factor for Ranbaxy's next expansion for maintaining sustainable growth and position in the international market. European countries like Cyprus and Greece could be the location choice for next market expansion. In case of choosing European countries, Ranbaxy could minimize psychic distance, technological, economical, and institutional and location distance as it has strong local image in the European countries (Linnemann, 1966; O'Grady \& Lane, 1996). First, Ranbaxy can move towards Cyprus and later to Greece because in case of market regulations and culture both are similar (www.cyprus.gov.cy and www.ancientgreece.com).

Now question is why Cyprus is more lucrative for the next expansion. Following criteria will signify the importance: (country website, www.eu.com and existing literature.)

1) In order to further enhance of the foreign investment intensity, government has liberalized the foreign direct investment (FDI) policy not only for EU citizens but also for investors from third countries in most sector of the economy as from $1^{\text {st }}$ of October 2004 (www.cyprus.gov.cy).

2) Limitations related to minimum level of investment and foreigners participation percentage have been abolished, in most sectors of the economy, allowing for up to $100 \%$ for equity participation in registering companies or acquiring shares in existing companies (www.cyprus.gov.cy).

3) Administrative procedures have been simplified and measures have been taken to streamline the infrastructure regarding foreign investment.

4) Wide generics drug market and branded prescription drug market

5) Handsome amount of per capita health expenditure

6) Increasing trend of GDP of the country

7) Consequently foreign companies now have the opportunity of investing and establishing business in Cyprus on equal terms with local investors.

8) Democratic country with a liberal market economy

9) Member state of European Union

10) Strategic location at the crossroad of three continents

11) Excellent telecommunications

12) Modern and efficient legal accounting and banking services

13) Favourable tax regime including $10 \%$ rate of corporation tax (www.cyprus.gov.cy)

14) Low operating and establishment cost

15) Availability of highly qualified technical, clerical and managerial people.

Acquisition seems like one of the best entry modes for the Ranbaxy's next expansion in Cyprus. To overcome liability of foreignness, Ranbaxy usually followed acquisition strategy in most of the regulated markets (Appendix 3) especially in North American and European market (Yeoh, 2011). Compare to other entry modes acquisition can help to overcome regulatory related and credibility problems more effectively (Chittoor \& Ray, 2007). In addition, firms can offer their product and services more confidently by maintaining both qualities as well as safety standards (Dixit \& Yadab, 2008). Furthermore, according to CEO of Ranbaxy, "with the acquisition of $\mathrm{Ohm}$ laboratories we no longer have to worry about the delays of FDA approvals. Such acquisitions were also helped Ranbaxy to get rid of the 'made-in-India' image for our very discerning US customers" (Annual report, 1995).

After selecting location and entry mode, company should give focus developing marketing strategies. Pharmaceutical product marketing is different from consumer product. In case of pharmaceutical product offering, the main focal points are quality, efficacy and side effects of the products. For generic drugs most of the 
consumer look at the price, quality and dosage convenience. For the prescription drugs, consumers are fully depending on medical professionals prescribing habit. In this context, country to country there are no significant variations in case of pharmaceutical products offering as well as marketing. Table 7 depicts Ranbaxy's product offering in different geographic region. From the table it is worthwhile to draw a conclusion; there is no alternative except standardization strategy in case of pharmaceutical product offering.

Table 7. Product offered Ranbaxy in the different geographical segments

\begin{tabular}{ll}
\hline Region & Product offered \\
\hline Africa & Anti-infective, Anti-viral segment \\
Asia & Anti-infective, Anti-inflammatory, and Anti-viral segment \\
USA and Europe & Anti-inflammatory, Anti-viral, Anti-infective, Anti-diabetic segment, Cardiovascular, \\
Latin America & Anti-inflammatory, Anti-viral, Anti-infective, Anti-diabetic segment, Cardiovascular, \\
Japan & Anti-infective, Anti-viral, Anti-inflammatory, Cardiovascular, Anti-diabetic segment \\
\hline
\end{tabular}

Source: Developed by the authors based on company website, annual reports and literature

Pricing is another important part of marketing mix. Management of Ranbaxy must analyze the interactive effect that pricing has on the other elements of the mix, and how pricing can assist achieving the overall company objectives. In this case cost based pricing or competition based pricing strategy can be the best to adopt. Furthermore, in case of pricing, government price restrictions and policy have to be considered because some countries have restrictions on some special product pricing. For example, Bangladesh government has a policy of control on Chloramphenicol product pricing.

Distribution is the third element of marketing mix. An advantage of acquisition strategy is that, usually the sold company had a network used to distribute their products. Ranbaxy will adopt this network. Sequentially, it can be changed if needed to increase the efficiency of the network.

The last element of marketing mix is promotion and it is well known that pharmaceutical products promotion is different from other products. For the generic products some countries allow limited advertisement but for prescription product nowhere advertisement is allowed. If specific country government allows advertising (e.g. Bangladesh government has a policy of restriction on pharmaceutical product advertising) for generic products, Ranbaxy should take initiative to advertise using both electronic and print media by highlighting the benefits of dosage convenience, quality and cost. For the prescription product company should use personal selling as a promotional tool. Well trained sales people will be deployed communicating with the medical professionals for generating prescriptions. They will try to convince the medical professionals by highlighting feature and the benefits of the drugs by showing scientific study and trial reports.

\section{Conclusion}

In consistent with the OLI framework, Ranbaxy utilized ownership advantage (i.e. low cost production) in the first step of internationalization process. To move forward to the pharmaceutical value chain, it was obvious to capture dynamic capabilities. For this reason, it has chosen location choices very carefully with the objective of developing potential absorptive capabilities (i.e. knowledge associated with institutional context, social relationship and economic condition in a specific country) (Rugman \& Verbeke, 2003; Yeoh, 2011). Market seeking motives of FDI by emerging multinationals is consistent with the tenets of Uppsala Stages Model which argues that firm's incremental internationalization can be treated as one of overcoming psychic distance related to culture (Johnson \& Vahlne, 1977). To overcome the liability of foreignness usually MNCs from emerging economies followed the incremental stages of Uppsala Stages model. But in case of Ranbaxy, skipping earlier stages moved to 'merger and acquisitions' have called into question the sequential view of firm's internationalization.

This case study has been revealed that early stage of the internationalization process of Ranbaxy was sequential from unregulated to regulated market. Gaining experience and knowledge from Africa and Asian market it moved to USA and Europe. Ranbaxy has been chosen entry mode as 'acquisition' for USA and European market basically to overcome made-in-India image, credibility issues and quality concern. Furthermore, Ranbaxy offered their product and services more confidently as a guarantor of quality and safety standards due to acquisition strategy (Dixit \& Yadab, 2008). For the next expansion Ranbaxy has enough experience and 
capabilities to exploit the market potential. Considering all an inference can be drawn that it will move to the world market and gain strong foothold in various geographic segments as a giant player in the international pharmaceutical market.

\section{References}

Anderson, O. (1993). On the Internationalization Process of Firms: A Critical Analysis. Journal of International Business Studies, 24(2), 209-231. http://dx.doi.org/10.1057/palgrave.jibs.8490230

Athreye, S., Kale, D., \& Ramani, S. V. (2009). Experimentation with strategy and the Evolution of Dynamic Capability in the Indian Pharmaceutical Sector. Industrial and Corporate Change, 18(4), 729-759. http://dx.doi.org/10.1093/icc/dtp024

Chaudhury, S. (1997). The Evolution of the Indian Pharmaceutical Industry. In G. Felker et al. (Eds.), The Pharmaceutical Industry in India and Hungary: Policies, Institutions and Technological Development (No. 392, pp. 42-86). World Bank Technical Paper.

Chaudhury, S. (2004). The Pharmaceutical Industry. In S. Gokarn et al. (Eds.), The Structure of Indian Industry. The Oxford University Press, New Delhi.

Chittoor, R., \& Ray, S. (2007). Internationalizations Paths of Indian Pharmaceutical Firms-a Strategic group $\begin{array}{llll}\text { analysis. Journal of International } & \text { Management, } & \text { 13(3), }\end{array}$ http://dx.doi.org/10.1016/j.intman.2007.05.008

CRIS INFAC. (2004). Pharmaceutical Annual Review. February 2004, Mumbai, India.

Cyprus. (2011). Official Website. Retrieved April 16, 2011, from http://www.cyprus.gov.cy

Dixit, M. R., \& Yadav, S. (2008). Motivation, Capability Handicaps and Firm Responses in the early phase of Internationalization From Emerging Economies: A Study on the Indian Pharmaceutical Industry. Working Paper Series, no-2008-02-05, Indian Institute of Management, India.

Dunning, J. H. (1988). The Eclectic Paradigm of International Production: A Restatement and Some Possible Extensions. Journal of International Business Studies, 19(1), 1-31. http://dx.doi.org/10.1057/palgrave.jibs. 8490372

Dunning, J. H. (1993). Multinational enterprises and the global economy. Wokingham, England and Reading, Mass, Addison Wesley.

Dunning, J. H. (2000). The Eclectic Paradigm as an Envelope for Economic and Business Theories of MNE Activity. International Business Review, 9, 163-190. http://dx.doi.org/10.1016/S0969-5931(99)00035-9

Greece. (2011). Official Website. Retrieved April 16, 2011, from http://www.ancientgreece.com

India's Most Comprehensive Pharma Portal. (2010). Official Website. Retrieved April 15, 2011, from http://www.pharmabiz.com

Johanson, J., \& Mattson, L. G. (1988). Internationalization in industrial systems: A network approach. In N. Hood, \& J. E. Vahlne (Eds.), Strategies in global competition (pp. 194-213). London: Croom Helm.

Johanson, J., \& Vahlne, J. E. (1977). The Internationalization process of the firm-a model of knowledge development and increasing foreign market commitments. Journal of International Business Studies, 8(1), 23-31. http://dx.doi.org/10.1057/palgrave.jibs.8490676

Krajewshi, L. J., \& Ritzman, L. P. (2005). Operations Management (7th ed.). Pearson Education, India.

Kumar, N., \& Pradhana, J. P. (2002). Economic Reforms, WTO and Indian Drugs and Pharmaceuticals Industry: Implications of Emerging Trends. CMDR Monograph Series No. 42, Centre for Multidisciplinary Development Research (CMDR), and Dharwad1-45.

Li, P. P. (2007). Toward an integrated theory of multinational evolution: The evidence of Chinese multinational enterprises as latecomers. Journal of International management, 13(3), 296-318. http://dx.doi.org/10.1016/j.intman.2007.05.004

Linnemann, H. (1966). An Econometric Study of International Trade Flows. Amsterdam: North-Holland Publishing Company.

Masum, M. I. (2012). Internationalization Process of Buying Houses in Bangladesh: An Evaluation. ASA University Review, 6(2), 171-184.

Nigam, R., \& Su, Z. (2010). Flying towards the successful skies: The emerging region multinationals. Journal of 
Emerging Knowledge on Emerging Markets, 2, 159-180. http://dx.doi.org/10.7885/1946-651X.1023

Nigam, R., \& Su, Z. (2011). Management in Emerging versus Developed Countries: A Comparative Study from an Indian Perspective. Journal of Centrum Cathedra, 4(1), 121-133. http://dx.doi.org/10.7835/jcc-berj-2011-0054

O'Grady, S., \& Lane, H. W. (1996). The Psychic Distance Paradox. Journal of Business Studies, 27(2). http://dx.doi.org/10.1057/palgrave.jibs.8490137

Pharmaceutical Industry Related Magazine. (2010). Official Website. Retrieved April 15, 2011, from http://www.google.com.bd/search?q=iii+pharmainfo+net+magazine\&channel=linkdoctor

Ranbaxy laboratories Ltd. (2011). Ranbaxy's Official Website. Retrieved April 15, 2011, from http://www.ranbaxy.com/operations/operationcountry.aspx

Reiffen, D., \& Ward, D. (2005). Generic Drug Industry Dynamics. The Review of Economic and Statistics, 87(1), 37-49. http://dx.doi.org/10.1162/0034653053327694

Rugman, A. M., \& Verbeke, A. (2003). Extending the Theory of the Multinational Enterprise: Internalization and Strategic Management Perspectives. Journal of International Business Studies, 34(2), 125-137. http://dx.doi.org/10.1057/palgrave.jibs.8400012

Sampath, G. P. (2005). Economic Aspects of Access to Medicines after 2005: Product Patent Protection and Emerging Firm Strategies in the Indian Pharmaceutical Industry. CIPIH.

Yeoh, P. (2011). Location Choice and the Internationalizations sequence: Insight From Indian Pharmaceutical $\begin{array}{llll}\text { Companies. International } & \text { Marketing 291-312. }\end{array}$ http://dx.doi.org/10.1108/02651331111132866

\section{Copyrights}

Copyright for this article is retained by the author(s), with first publication rights granted to the journal.

This is an open-access article distributed under the terms and conditions of the Creative Commons Attribution license (http://creativecommons.org/licenses/by/3.0/). 